\title{
Morphological Changes in Sugarcane as a Function of Metallurgic Slag and Gypsum
}

\author{
Paulo R. A. Clemente ${ }^{1}$, Benigno F. A. de Almeida ${ }^{1}$, Diogo H. de A. B. ${ }^{1}$, André L. J. Silva ${ }^{1}$, \\ Vinicius S. G. da Silva ${ }^{2} \&$ Laurício Endres ${ }^{1}$ \\ ${ }^{1}$ Center of Agricultura Sciences, Federal University of Alagoas, Rio Largo, Alagoas, Brazil \\ ${ }^{2}$ Pernambuco Federal Institute of Education, Science, and Technology,Vitória de Santo Antão, Pernambuco, \\ Brazil \\ Correspondence: Vinicius S. G. da Silva, Pernambuco Federal Institute of Education, Science, and Technology, \\ Vitória de Santo Antão, PE, Brazil. Tel: 55-819-572-3906. E-mail: vinicius.agro2008.1@gmail.com
}

Received: March 5, 2019

Accepted: June 10, 2019

Online Published: August 31, 2019

doi:10.5539/jas.v11n14p291

URL: https://doi.org/10.5539/jas.v11n14p291

\begin{abstract}
Drought associated with soil acidity and exchangeable $\mathrm{Al}^{3+}$ in depth are one of the main limiting factors in agricultural production in Northeast Brazil. Acidity correctives such as limestone, metallurgy slag, and gypsum are alternatives to minimize the effects of seasonal droughts on the crop. A field study was carried out to evaluate the effect of the slag and gypsum on the morphological aspects and productivity of sugarcane during two crop cycles. A randomized block design in subdivided plots scheme with four replications was used. The plot consisted of five rows of $10 \mathrm{~m}$ length each, spaced $1 \mathrm{~m}$ from each other. Treatments consisted of five levels of metallurgy slag $\left(0 ; 1 ; 2 ; 3\right.$ and $\left.4 \mathrm{Mg} \mathrm{ha}^{-1}\right)$ and two levels of gypsum $\left(0\right.$ and $\left.1.9 \mathrm{Mg} \mathrm{ha}^{-1}\right)$. Slag and gypsum had no effect on sugarcane plant yield. However, regarding sugarcane ratoon, slag increased the yield per hectare by $1.96 \mathrm{Mg} \mathrm{ha}^{-1}$ and sugar yield by $0.33 \mathrm{Mg} \mathrm{ha}^{-1}$ per Mg of applied slag. Slag and gypsum provided better biomass allocation to the root system and improved root distribution along the soil profile.
\end{abstract}

Keywords: drought stress, phenology, root system, Saccharum spp., silicon

\section{Introduction}

Brazil is the largest producer of sugarcane in the world with approximately 9.1 million hectares of planted area and with an estimated total production of 694.5 million tons (2016/2017 harvest), which will be transformed into 39.8 million tons of sugar and 27.9 billion liters of ethanol (CONAB, 2016).

The average yield of Brazilian sugarcane is considered low compared to its biological potential, which can exceed $300 \mathrm{t} \mathrm{ha}^{-1}$ (Landell, 2006). Water deficit is the main factor limiting sugarcane productivity around the world (Jangpromma et al., 2010).

The use of silicon stands out among the several agronomic practices used to mitigate the effect of water stress in plants (Crusciol et al., 2009; Mauad et al., 2011). The physiological effects are related to increased photosynthetic activity, resistance to pest and disease and plant tolerance to drought (Crusciol et al., 2009).

Sugarcane is considered a silicon-accumulating species, with can accumulate $0.14 \%$ of this element in young leaves, reaching up to $6.7 \%$ in stalks and old leaves, been able to extract up to $500 \mathrm{~kg}$ of silicon per hectare under suitable conditions of Si supply (Korndörfer et al., 2002).

Gypsum is another agricultural input used to minimize the effect of drought stress. It all improves the distribution of roots in depth and allows plants to use more water and nutrients, especially during drought periods. The use of gypsum in sugarcane has increased root growth in depth, providing, more absorption of water and nutrients resulting in higher crop yield (Morelli et al., 1992; Rocha et al., 2008).

The hypothesis suggested in this study is that the use of metallurgy slag associated with gypsum has a synergistic effect of favoring root growth in depth and, thereby, minimize the effects of water deficit and increase sugarcane yield. Thus, this study aimed to evaluate the morphological and yield changes in sugarcane subjected to the use of metallurgy slag associated with gypsum in plant and ratoon sugarcane crop. 


\section{Material and Methods}

\subsection{Caracterization of Experimental Area}

The research was carried out in field condition between late 2011 and early 2013, at the geographic coordinates $9^{\circ} 25^{\prime} \mathrm{S}$ and $36^{\circ} 06^{\prime} \mathrm{W}$. The soil in the region is classified as Fluvic Neosol or Fluvisols (Embrapa, 2013). The rainy tropical climate predominates in the region with dry summer (As'), with an average annual rainfall of $1,309.9 \mathrm{~mm}$ (Koffler, 1986). The average temperature in the region is $25^{\circ} \mathrm{C}$, with a maximum of $30^{\circ} \mathrm{C}$ and a minimum of $20^{\circ} \mathrm{C}$. The average cumulative rainfall during the study was 1,691 and $928 \mathrm{~mm}$ in the first and second crop years, respectively (Figure 1).

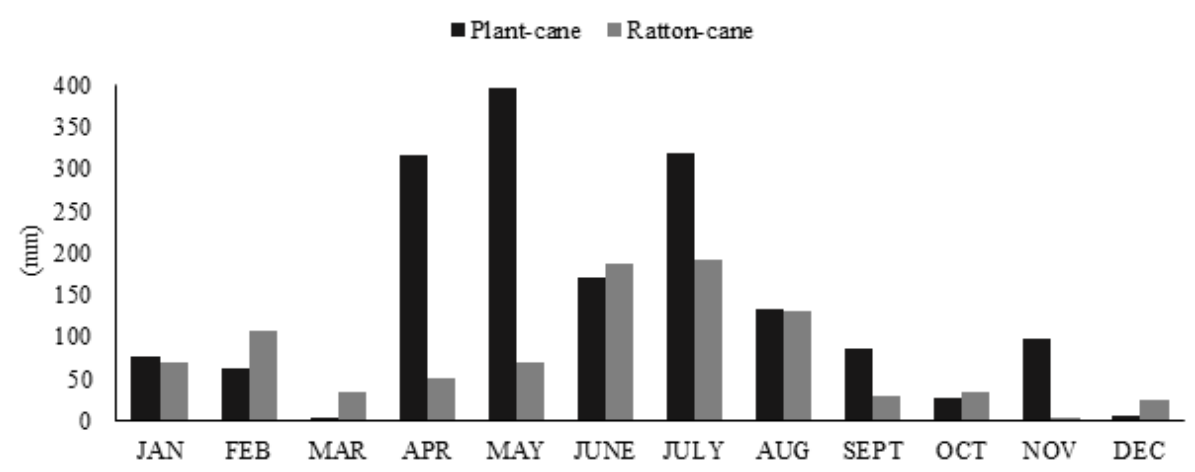

Figure 1. Mensal average rainfall during the study

Before the implantation of the experiment, chemical and physical analyses of soil (Table 1) were performed at three depths along the profile in the 0-20, 20-40 and 40-60 cm layers, (EMBRAPA, 2009).

Table 1. Chemical and physical soil characterization

\begin{tabular}{|c|c|c|c|c|c|c|c|c|c|c|c|c|c|c|c|}
\hline Depth & $\mathrm{pH}$ & $\mathrm{Ca}$ & $\mathrm{Mg}$ & K & $\mathrm{Al}$ & $\mathrm{H}+\mathrm{Al}$ & CTC & $\mathrm{P}$ & $\mathrm{Fe}$ & $\mathrm{Cu}$ & $\mathrm{Mn}$ & $\mathrm{Zn}$ & V & $\mathrm{m}$ & OMS. \\
\hline $\mathrm{cm}$ & $\mathrm{H}_{2} \mathrm{O}$ & --- & 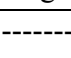 & $---\mathrm{cm}$ & $21_{c} d m$ & -3 & ----- & ---- & ----- 1 & $\mathrm{~g} \mathrm{dm}$ & -3--.. & --- & ------ & $\%$ & dag $\mathrm{kg}^{-1}$ \\
\hline $0-20$ & 5.3 & 2.1 & 2.0 & 0.08 & 1.0 & 4.5 & 8.71 & 6.0 & 196.5 & 0.7 & 13.1 & 1.0 & 48.3 & 19.2 & 2.98 \\
\hline $20-40$ & 4.9 & 1.1 & 0.3 & 0.07 & 1.4 & 5.1 & 6.61 & 1.0 & 138.3 & 0.6 & 1.9 & 0.2 & 22.8 & 48.1 & 1.91 \\
\hline $40-60$ & 4.9 & 0.8 & 1.2 & 0.06 & 1.2 & 4.2 & 6.30 & 1.0 & 104.3 & 0.7 & 0.7 & 0.1 & 333 & 36.3 & 2.28 \\
\hline Depth & BD & & & PD & & & Sand & & & Silt & & & Cla & & \\
\hline $\mathrm{cm}$ & ---- & & 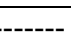 & $\mathrm{cm}^{-3}$ & & & & & & 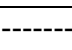 & $\mathrm{g} \mathrm{Kg}$ & & & & \\
\hline $0-20$ & 1.19 & & & 2.56 & & & 510 & & & 110 & & & 380 & & \\
\hline $20-40$ & 1.06 & & & 2.60 & & & 370 & & & 150 & & & 480 & & \\
\hline $40-60$ & 1.03 & & & 2.67 & & & 410 & & & 50 & & & 540 & & \\
\hline
\end{tabular}

Note. SOM-Organic matter of soil.

\subsection{Experimental Design}

A randomized complete block experimental design in split plot scheme, with four replications was used. Treatments consisted of the combination of five levels of metallurgy slag $\left(0 ; 1 ; 2 ; 3\right.$ and $\left.4 \mathrm{Mg} \mathrm{ha}^{-1}\right)$ applied in the plot, and with two levels of gypsum $\left(0\right.$ and $\left.1.9 \mathrm{Mg} \mathrm{ha}^{-1}\right)$ applied in the subplots before planting. Each subplot was composed of five rows of sugarcane with $10 \mathrm{~m}$ length, spaced $1 \mathrm{~m}$ from each other, totaling $50 \mathrm{~m}^{2}$. Only the three central rows were used for quantitative analysis. The RB92579 variety was used at a planting density of 15 buds per meter.

The slag application was carried out in such a way as to provide a uniform distribution at the bottom of the planting furrow. The gypsum, in turn, was applied to cover the entire area, when the furrows had already been closed, according to the method described by Sousa et al. (2007).

The sugarcane planting was carried out between August and September 2010. It was used a fertilization of 600 $\mathrm{kg} \mathrm{ha}^{-1}$ of formulation $08-22-20$, based on the result of soil analysis collected before the experiment installation. At 150 days after planting (DAP), $60 \mathrm{~mm}$ of water was applied using a sprinkler irrigation system. 
At 470 DAP, sugarcane of the first cycle was harvested, then, it was performed a cover fertilization with $500 \mathrm{~kg}$ $\mathrm{ha}^{-1}$ of formulation 14-00-18. At 410 days after harvest (DAH), the sugarcane of the second cycle was harvested.

\subsection{Morphological Analysis}

The stalk height and diameter and leaf area were evaluated at 90,270 and 360 DAP in 10 plants of the central rows of each subplot. In addition to these measurements, the average tillering of each row was determined, counting the number of plants per meter of the furrow, in the three central rows of the plot.

The stalk height was measured using a measuring tape from the ground level to the leaf ligule +1 , and the stalk diameter was measured using a caliper on the middle third of the stalk. Leaf area was determined according to Hermann and Câmara (1999).

The same morphological analyses were performed for the sugarcane ratoon at 90, 300, and 390 DAH.

\subsection{Evaluation of Root Development}

After the harvest and cleaning the study area of the sugarcane plant and sugarcane ratoon, samples of soil and root were collected using an auger type "mug" (volume of $1.62 \mathrm{dm}^{3}$ ) in the layers of 0-20, 20-40 and 40-60 cm, for the evaluation of the sugarcane root development, according to the recommendations of Vasconcelos et al. (2003) with modifications. In each subplot, two soil and root samples were collected at $25 \mathrm{~cm}$ from the middle of the sugarcane row.

\subsection{Evaluation of Stalk and Sugar Yield}

Yield, in tons of stalk per hectare, was evaluated at 407 DAP and 410 DAH. For this purpose, the area was burned, and the three central rows of each subplot were cut. From the tons of stalk per hectare data and sugarcane sucrose, ton of pol per hectare was calculated (Fernandes, 2000).

\subsection{Statistical Analysis}

Data were subjected to analysis of variance at $5 \%$ probability by the F-test, and the means of the treatments were compared by the Tukey test. Data relating to slag rates were subjected to regression analysis and represented in graphs.

\section{Results and Discussion}

\subsection{Morphological Analysis}

Slag and gypsum had no influence on sugarcane growth in height in the two evaluated cycles. Corroborating the results of the present study, Madeiros et al. (2009) found similar results in sugarcane and Oliveira et al. (2013) in sunflower growth, which were not influenced by the application of metallurgy slag. However, in other studies, sugarcane plants had their height increased with the application of metallurgy slag (Prado et al., 2003; Madeiros et al., 2008; Sobral et al., 2011).

Gypsum had no effect on the stalk diameter in the two evaluated cycles. Slag only increased the stalk diameter at the end of the second crop cycle (Figure 2). These results corroborate those found by Madeiros et al. (2008) who observed an increase in stalk diameter with the application of $4 \mathrm{Mg} \mathrm{ha}^{-1}$ of metallurgy slag.

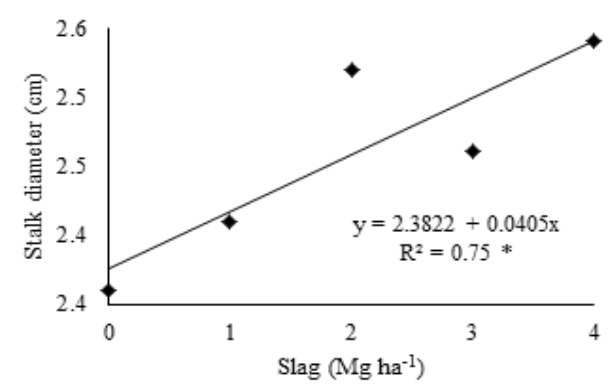

Figure 2. Sugarcane stalk diameter at $390 \mathrm{DAH}$ as a function of the use of metallurgy slag

\subsection{Stalk and Sugar Yield}

The yield of stalks and sugar was not influenced by the use of slag and gypsum in the first cycle. This fact can be attributed to the high vigor of sugarcane from the first cycle due to the use of the bud sett reserve. In addition, in during plant-cane crop, there was no water restriction (Figure 1) which favored the crop growth. Similar results 
were found by Leite et al. (2008), who found no effect of up to $450 \mathrm{~kg}$ of calcium silicate on sugarcane yield in an area with annual precipitation of $1493 \mathrm{~mm}$.

Regarding ratoon crop, yield of stalks and sugar increased linearly as a function of the slag levels (Figures $3 \mathrm{~A}$ and $3 \mathrm{~B}$ ). In this cycle, the water was restricted, with lower rainfall compared to the plant-cane crop (Figure 1). In the second crop cycle, yield of stalks increased by $15 \%$ with the highest level $\left(4 \mathrm{Mg} \mathrm{ha}^{-1}\right)$ compared to the control (Figure 3A). This increase in sugarcane yield in the ratoon-cane of cultivation is directly related to the slag residual effect (Korndörfer et al., 2000; Madeiros et al., 2008). Prado et al. (2003) report that silicate has a residual effect on soil, showing effects throughout the years of cultivation. Prado \& Fernandes (2009) found an increase in ratoon-crop production with the application of silicate levels. Prezotti and Martins (2012), also observed an increase in yield of stalks production with the application of silicate levels, corroborating the results of our study.
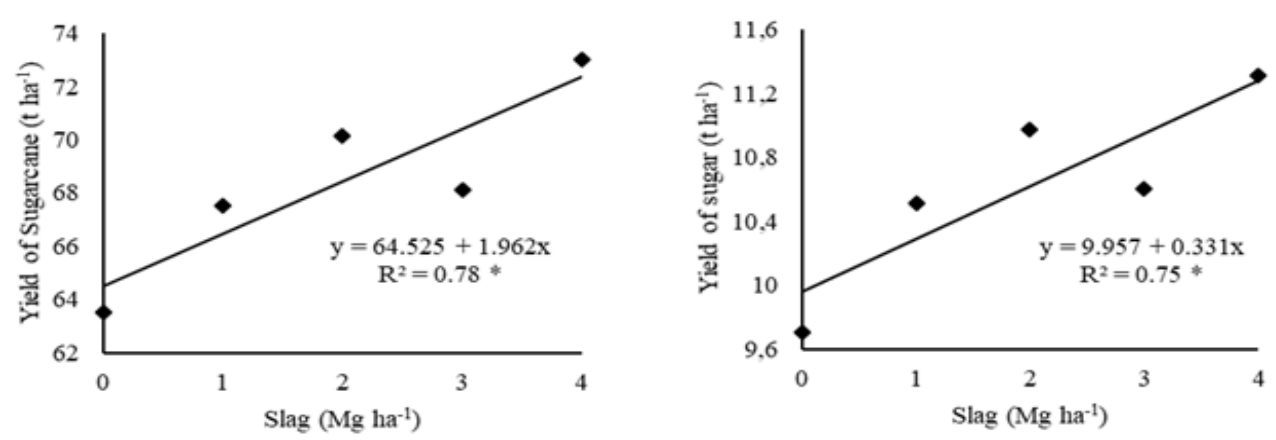

Figure 3. Sugarcane stalk yield (A.) and sugar yield (B.) as a function of the use of metallurgy slag

Yield of sugar also increased $17 \%$ comparing the level of $4 \mathrm{Mg} \mathrm{ha}^{-1}$ of slag to the control treatment (Figure 3B). A similar result was found by Ayres (1966) in Hawaii, who found an increase of $22 \%$ in sugar production, using $6.2 \mathrm{tha}^{-1}$ of calcium silicate.

\subsection{Root Dry Mass}

Root biomass was affected by gypsum and slag in the two cultivation cycles (Figure 4). The use of slag, gypsum, and slag + gypsum caused an increase in root mass of 16,42 and $80 \%$ in plant-cane and 5, 31 and $41 \%$ in ratoon-cane, respectively, in comparison with the control plants (Figure 4). Similar results were reported by Sousa et al. (2007) and Rocha et al. (2008) who found that the application of gypsum enhanced root growth in depth in sugarcane.

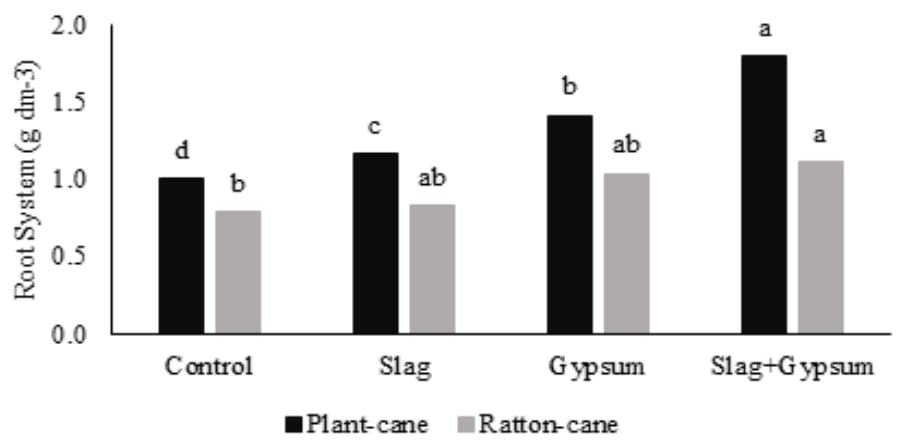

Figure 4. Dry root mass per soil volume as a function of the used slag and gypsum, in the plant-cane and ratoon-cane crop. Columns of the same color superscribed by different letters differ at $5 \%$ probability level by the Tukey Test

Although the root system of plant-cane was influenced by the use of slag and gypsum, yield was not affected in the first cultivation cycle. The good rainfall during this crop season may explain why increased root growth in depth was not decisive for yield maintenance. This not happened during the ratoon-cane crop when there were 
drought events during the cultivation cycle, and increased root biomass in depth (Figure 5) was fundamental for the sugarcane production.
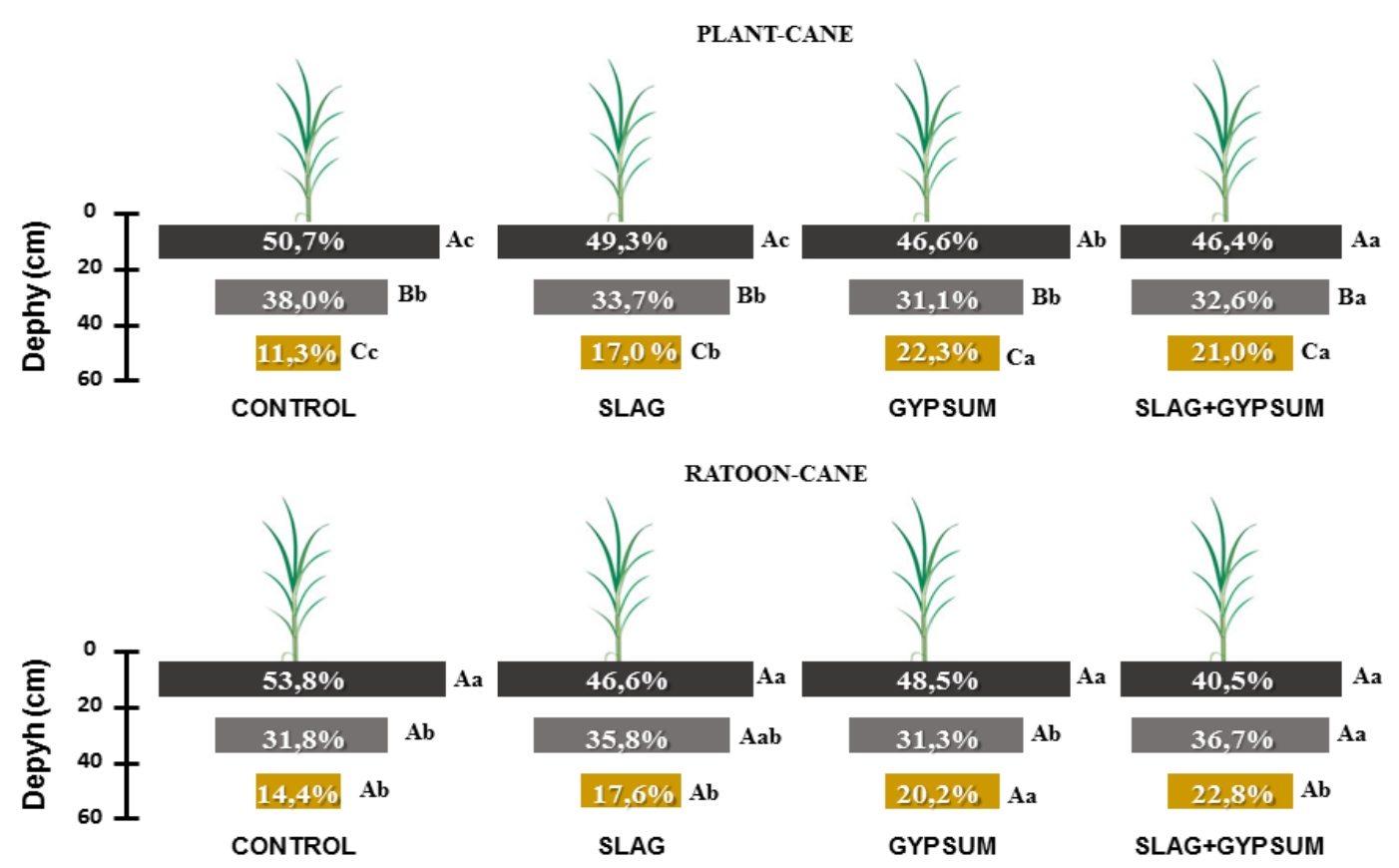

Figure 5. Relative distribution of plant-cane and ratoon-cane root biomass as a function of the se of slag and gypsum. Means superscribed by equal letters, both for treatments within the depths (lowercase letters) and for depths within the treatments (uppercase letters), do not differ at $5 \%$ probability level by the Tukey Test

The application of slag and gypsum also improved root distribution in depth (Figure 5). In plant-cane, there was a increase of 76, 176 and $333 \%$ in root mass with the use of silicon, gypsum, and silicon + gypsum, respectively, between 40 and $60 \mathrm{~cm}$ of depth. While, this increase was much less intense between 0 to $20 \mathrm{~cm}$ of depth. According to Morelli et al. (1992) and Sousa et al. (2007), the use of slag and gypsum allows a better root growth in depth and enhances the exploitation of soil volume and extraction of water and nutrients by sugarcane. This fact is due to the correction of acidity, in addition to providing calcium and magnesium in upper soil layer by the application of slag (Fernandes \& Prado, 2001), and higher solubility and mobility in the soil by application of gypsum, resulting in better root growth in depht and use of soil volume (Morelli et al., 1992; Rocha et al., 2008).

However, as it is observed in our experiment, the increase root growth in depth brings benefits to crop growth and yield only if the environmental conditions are restrictive in water availability in the soil, as occurred in ratoon-crop in our experiment.

Sugarcane has a poor distribution of root in depth. This can also differ among cultivar, being crucial for sugarcane cultivation in rainfed areas, with direct effect on crop yield (Costa et al., 2007). Therefore, the use of metallurgy slag and gypsum under dry conditions may be an alternative to improve the growth and distribution of sugarcane root system in depth.

\section{Conclusions}

1) Metallurgy slag and gypsum had no effect on plant-cane yield. However, stalk and sugar yield increased in ratoon-cane with the use of slag.

2) The use of slag combined with gypsum provided a higher biomass allocation to the sugarcane roots in the two crop cycles, and there was also a better root distribution in the soil depth.

3) The use of slag and gypsum in sugarcane can be recommended for regions with seasonal droughts events where the increase of the root system can be decisive for the yield maintenance under water deficit conditions. 


\section{References}

Ayres, A. S. (1996). Calcium silicate slag as a growth stimulant for sugarcane on lowsilicon soils. Soil Science, 101, 216-227. https://doi.org/10.1097/00010694-196603000-00009

Embrapa (Brazilian Agricultural Research Corporation). (2009). Manual of soil analysis methods (2nd ed.). Rio de Janeiro: Embrapa.

Embrapa (Brazilian Agricultural Research Corporation). (2013). Brazilian Soil Classification System (3rd ed.). Brasília: Embrapa.

CONAB (National Supply Company). (2016). Acompanhamento da safra brasileira: Cana-de-açúcar. Primeiro Levantamento.

CONSECANA (Sugarcane, Sugar and Alcohol Producers Council of the State of São Paulo). (2006). Manual de instruções (5th ed., p. 112). Piracicaba, Brazil.

Costa, M. C. G., Mazza, J. A., Vitti, G. C., \& Jorge, L. A. C. (2007). Root distribution, plant nutritional status, and stalk and sugar yield in two genotypes of sugarcane in distinct soils. Revista Brasileira de Ciência do Solo, 31, 1503-1514. https://doi.org/10.1590/S0100-06832007000600027

Crusciol, C. A. C., Pulz, A. L., Lemos, L. B., \& Lima, G. (2009). Effects of silicon and drought stress on tuber yield and leaf biochemical characteristics in potato. Crop Science, 49, 949-954. https://doi.org/10.2135/ cropsci2008.04.0233

Fernandes, A. C. (2000). Calculations in the sugarcane agroindustry (p. 193). Piracicaba: STAB-Sugar, Alcohol and Subproducts.

Hermann, E. R., \& Câmara, G. M. S. (1999). A simple method to estimate the leaf area of sugarcane. Revista da STAB, 17, 32-34.

Jangpromma, N., Songsri, P., Thammasirirak, S., \& Jaisil, P. (2010). Rapid assessment of chlorophyll content in sugarcane using a SPAD chlorophyll meter across different water stress conditions. Asian Journal of Plant Sciences, 9, 368-374.

Koffler, N. F. (1986). Caracterização edafo-climática das regiões canavieiras do Brasil (1st ed.). IAA-PLANALSUCAR, Piracicaba.

Korndörfer, G. H., Benedini, M., Paula, F. B., \& Chagas, R. C. S. (2000). Cimento como fonte de silício para a cana-de-açúcar. Revista STAB, 19, 30-33.

Korndörfer, G. H., Pereira, H. S., \& Camargo, M. S. (2002). Papel do Silício na Produção de Cana-de-Açúcar. Revista STAB, 21, 6-9.

Landell, M. G. A., Xavier, M. A., Anjos, I. A., Vasconcelos, A. C. C. M., Pinto, L. R., \& Creste, S. (2006). Potencialidade de novas variedades de cana-de-açúcar. In M. O. Marques, M. A. Muttom, A. A. P. M. Azania, L. C. Tasso-Junior, G. A. Nogueira, \& D. W. Vale (Eds.), Tópicos em tecnologia Sucroalcooleira (Vol. 1, pp. 17-30).

Leite, G. M. V., Andrade, L. A. B., Garcia, J. C., \& Anjos, I. A. (2008). Effects of sources and dosages of calcium silicate on yeld and quality of sugarcane, cultivar SP80-1816. Ciência e Agrotecnologia, 32, 1120-1125. https://doi.org/10.1590/S1413-70542008000400013

Liang, Y. C., Sun, W. C., Si, J., \& Römheld, V. (2005). Effects of foliar and root applied silicon on the enhancement of induced resistance to powdery mildew in Cucumis sativus. Plant Pathology, 54, 678-685. https://doi.org/10.1111/j.1365-3059.2005.01246.x

Madeiros, L. B., Vieira, A. O., Neto, J. D., Beltrão, N. E. M., \& Aquino, B. F. (2008). Influence of siderurgical slag on productivity and crop growth of irrigated sugarcane. Engenharia Ambiental, 5, 192-202.

Madeiros, L. B., Vieira, A. O., \& Aquino, B. F. (2009). Influence of siderurgical slag about gaseous changes and production of biomass of sugarcane. Engenharia Ambiental, 6, 121-129.

Mauad, M., Crusciol, C. A. C., \& Filho, H. G. (2011). Dry matter and plant nutrition of upland rice under water deficit and silicon fertilization. Semina: Ciências Agrárias, 32, 939-948. https://oi.org/10.5433/ 1679-0359.2011v32n3p939

Morelli, J. L., Dalben, A. E., Almeida, J. O. C., \& Demattê, J. L. I. (1992). Calcário e gesso na produtividade da cana de açúcar e nas características químicas de um Latossolo de textura média Álico. Revista Brasileira de Ciência do Solo, 16, 187-194. 
Oliveira, J. T., Campos, V. B., Chaves, H. G., \& Guedes Filhos, D. H. (2013). Silicon fertilization on growth of ornamental sunflower cultivars. Revista Brasileira de Engenharia Agrícola e Ambiental, 17, 123-128. https://doi.org/10.1590/S1415-43662013000200002

Prado, F. M., \& Fernandes, F. M. (2001). Response of sugar cane to application of slag as a corrective agent for acidity in soil. Revista Brasileira de Ciência do Solo, 25, 199-207. https://doi.org/10.1590/S0100-06832001 000100021

Prado, F. M., Fernandes, F. M., \& Natalie, W. (2003). Residual effect of calcium silicate slag as soil acidity corrective in sugar cane rattoon. Revista Brasileira de Ciência do Solo, 27, 287-296. https://doi.org/ $10.1590 / \mathrm{S} 0100-06832003000200009$

Prado, F. M., \& Fernandes, F. M. (2009). Economic aspect of the use of the slag of siderurgy in the sugar cane during five cycles of production. Terra Latinoamericana, 28, 273-279.

Prezotti, L. C., \& Martins, A. G. (2012). Soil chemical characteristics, nutrients and heavy metal elements in sugar cane crop as function of steel slag doses. Revista Ceres, 59, 530-536. https://doi.org/10.1590/ S0034-737X2012000400014

Quaggio, J. A. (2000). Acidez e calagem em solos tropicais. Instituto Agronômico, Campinas, Brazil.

Rocha, A. T., Oliveira, A. C., Rodrigues, A. N., Junior, M. A. L., \& Freire, J. F. (2008). Use of Araripe gypsum to improve sugarcaneroot environment. Revista Brasileira de Ciências Agrárias, 3, 307-312. https://doi.org/ 10.5039/agraria.v3i4a282

Scholander, P. F., Bradstreet, E. D., Hemminngsen, E. A., \& Hammel, H. T. (1965). Sap pressure in vascular plants. Science, 148, 339-346. https://doi.org/10.1126/science.148.3668.339

Sobral, M. F., Nascimento, C. W. A., Cunha, K. P. V., Ferreira, H. A., Silva, A. J., \& Silva, F. B. V. (2011). Basic slag and its effects on the concentration of nutrients and heavy metals in sugarcane. Revista Brasileira de Engenharia Agrícola e Ambiental, 15, 867-872. https://doi.org/10.1590/S1415-43662011000800015

Sousa, D. M. G., Miranda, L. N., \& Oliveira, S. A. (2007). Soil acidity and its correction. In R. F. Novais, V. H. V. Alvarez, N. F. Barros, R. L. F. Fontes, R. B. Cantarutti, \& J. C. L. Neves (Eds.), Fertilidade do solo (Cap. 5, pp. 205-274). Sociedade Brasileira de Ciência do solo, Viçosa, Brazil.

Vasconcelos, A. C., \& Landell, M. G. A. (2003). Evaluation of the sugarcane root system with different methods. Avaliação do sistema radicular da cana de açúcar por diferentes métodos. Revista Brasileira de Ciências do Solo, 27, 849-858. https://doi.org/10.1590/S0100-06832003000500009

\section{Copyrights}

Copyright for this article is retained by the author(s), with first publication rights granted to the journal.

This is an open-access article distributed under the terms and conditions of the Creative Commons Attribution license (http://creativecommons.org/licenses/by/4.0/). 